\title{
BRAHMS AND CLARA SCHUMANN
}

\author{
BY FERDINAND SCHUMANN.'
}

\section{4}

$N$ OVEMBER 9. Brahms arrived here to-day from Viennin, and is living with us. . . At dinner I saw him for the first time in a long while-a corpulent little gentleman, with a full beard beginning to turn gray. The very odd mustache is fiery red on one side and gray on the other. His voice is unusually high and clear and sounds as if it were cracked. Brahms sat opposite to grandmother and was very lively and witty. The conversation was quite animated. In the evening attended a Museumgesellschaft concert. In honor of Brahms, the programme consisted entirely of works by him: Tragic overture, Variations on a theme by Haydn, the Violin concerto, the Hungarian dances arranged for violin and piano, and the $\mathrm{C}$ minor symphony.

G. F. Kogel conducted, Joachim was the soloist, and James Kwast was at the piano. Brahms sat in the front row with grandmother. She made an exception to her rule of not attending concerts, for she has become hard of hearing - cannot hear a tone, not even orchestral music, except forte passages. Besides, like grandfather before his end, she suffers from deceptive hearing, so that she imagines that she is continually hearing single tones and false harmonies. After Joachim had been applauded at the conclusion of the concerto, he left the platform and, pointing to Brahms, begged him to arise and thank the audience. Brahms turned to the public and there came a hurricane of applause, thunderous bravos and cheers. The orchestra played a fanfare. After the symphony Brahms stepped up to the platform, and again received an ovation.

November 10. Grandmother rode with me this morning to the house of Ladenburg, the banker, where the Joachim Quartet, just arrived from Berlin, rehearsed for the matinee which it will

1 These extracts are from a diury kept by the grandeon of Robert and Clare Schumann, who dwelt with the latter in Frantort. They date back to the years 1804 to 1806. Whenever Brahms visited Prankfort he was the gaest of his oldeat friend, the great pinnist Clara Schnmann. The extracts first appeared in the "Nene Zeitschrift for Musit," 1915, and are printed by permission.-Ir. 
give to-morrow. Otherwise, only Ladenburg's family were present. Brahms's B major quartet (Op. 67) was performed. The Master sat on a sofa smoking a cigar and was in a very good mood. At the close he applauded and exclaimed softly: "Bravo, bravo!" We followed the performance with the score. In the evening Brahms brought Herr Muhlfeld ${ }^{1}$ to supper, the artist having just come from Meiningen. For the first time we heard the newlycomposed clarinet sonata. Brahms was at the piano, grandmother at his right turning over the leaves. At the end of each movement she expressed her delight; Brahms would then ask: "Shall we go on?" and, observing her pleased nod, continued to play. . .

November 11. At eleven, matinee of the Joachim quartet in the small hall of the Saalbau concert-hall. Programme: Mozart, quartet G major (Kobchel, 387); Brahms, B major; Beethoven, A minor (Op. 132).

Brahms was present; there was much applause. For dinner Brahms and the Quartet were at Ladenburg's. In the evening the two clarinet sonatas were again performed at our house: Brahms and Muhlfeld. Ludwig Rottenberg, the conductor of the opera orchestra, was present. He came from Vienna, and enjoys Brahms's particular esteem. A brother of Muhlfeld's, oboist and Musikdirektor in Wiesbaden, was also present. After the first sonata, Joachim came in.

When playing, Brahms utters very peculiar sounds-one might call them a sort of gasping, grumble or snoring. After the first sonata Muhlfeld's brother addressed various compliments to the Master, who, pacing up and down the room, paid no attention to him. He would glance at him for some moments, turn his back and keep on walking and smoking. ... After supper, punch in the salon. Brahms remarked of the clarinet that its tone was much more adapted to the piano than string instruments. The tone-character of the latter was quite different. The clarinet, as a solo instrument as well as in chamber music, should be more cultivated than it had been.

The most wonderful thing about Brahms is his peculiarly blue eyes. He wears his hair rather low over the back of the coat collar, closely cut on each side. Occasionally he wears a pince-nez. At nine in the morning he takes brealfast with us. Later on I hear, much to my surprise, that as early as seven he is at work in his room, so that the breakfast with us is practically a second meal. 
In the evening we all visited my uncle, Louis Sommerhoff, grandmother's son-in-law. The company assembled in honor of Brahms. . . It includes the Joachim Quartet, Ladenburg and Herr Bertuch, the translator of Frederic Mistral's Mireio. The clarinet trio, by Mozart, with grandmother at the piano, and Joachim playing the viola.

November 19. At one o'clock grandmother and Muhlfeld played grandfather's "Phantasiestucke," Op. 73. Earlier in the day, while walking with her, she expressed to me her pleasure at being able to play with this excellent artist, and called my attention to the fact that in those pieces the violin was no adequate substitute for the clarinet. Had grandfather had the opportunity to hear them with a clarinet they would have made an entirely different impression upon him, for, as so often happens, a violin was used because it was difficult to obtain a wind player.

At dinner Brahms and Muhlfeld were again the guests. The subject of conversation is Joachim, who had departed for Winterthur where he was to play in Ernst Radeke's Society. Brahms admires Joachim's endurance. On his travels, he said, Joachim's capacity for sleeping was enviable, but he was a poor skat player. We then talk about Hans von Bulow, whose conducting at concerts from memory Brahms did not "think astonishing; but that he also directed the rehearsals without notes was, in his opinion, a wonderful thing." The scores Bulow would practically commit to memory beforehand. (He had just died in Cairo.)

In the evening a musical gathering at our home, also in honor of Brahms. I observe many gentlemen on the staff of the Hoch Conservatory: Ernst Engesser, Lazzaro Uzielli, Iwan Knorr, Hugo Heermann, Naret Koning, as well as my professor in musical theory, Anton Urspruch, of the Raff Conservatory. . . Gustav Erlanger, Johann Hegar, a son of the Zurich composer, who is studying in Frankfort with Hugo Becker. Most of the gentlemen were accompanied by their wives. Frau Julia Uzielli sang songs by Brahms; afterwards the two clarinet sonatas were played by Brahms and Muhlfeld, and grandfather's clarinet pieces, with grandmother at the piano. The company was very animated, and my grandmother, in spite of her seventy-six years, did the honors.

November 15. I hear that last night Brahms had expressed his opinion concerning the proposed monument to Bulow in Hamburg. He is opposed to it, in spite of his friendship for Bulow. He declined to contribute to the fund. He did not think a monument should be erected to the memory of a man, who had 
left nothing behind [sic!], and who had created no new epoch in music. That it was not stinginess on his part was proved by his frequent and liberal contributions to funds for the benefit of orchestral players, etc. Bulow was an eminently gifted conductor, but that did not entitle him to a monument.

1895.

February 11. Brahms has just written from Leipzig. His letter reads:

Drar Clara:

To hear your dear Leipzig heartily praised must surely afford you a genuine gaudium. If you therefore let me describe my eight days there, you shall have that pleasure. It was really one of the most enjoyable concert adventures that I ever experienced. Everything was so successful that it becomes difficult to point out any of the details. First of all, the weather, which doesn't often give us much satisfaction there, but which I enjoyed every day; then Herr Kraft (Hotel de Prusse) saw to it that I lived like a prince, and paid like an humble citizen. The one thing better than the other. Orchestra Quartet D'Albert, Muhlfeld, the public, the management, then the Museum Klinger ${ }^{1}$ and what not. That the whole thing impressed others as being fine you may infer from the facts that D'Albert received two hundred Marks more than usual, while I - who had expected only my travelling expenses - was presented with two thousand! Besides which, the management gave a grand banquet to one hundred and sirty persons at my hotel. . .

That the two piano concertos should have been given one after the other, you can hardly, or, at least, reluctantly imagine. But you would have endured it, for at the rehearsal as well as at the concert, everything went so smoothly as to seem a matter of course. At the concluding overture I waited in vain for some one to leave the hall. You will find the intermediate selections a cause for wonder. But these, too, were just right, because the singer (Eriks Wedekind) was really a most charming young girl, who sang admirably. (Pupil of Frl. Orgeni, whom on this occasion I saw again.)

This chatter of mine seems trifling in every way. But to do better is impossible, owing to the innumerable letters stacked up here. For you are only to take pleasure in your Leipzig and incidentally at the beautiful days it gave me. On the fourteenth there is to be a rehearsal of the clarinet quintet in Frankfort. Couldn't that be done at your house, so that you could listen to it in perfect comfort? On the 15th, Mannheim; 16th, Frankfort; 17th, Rudesheim-Beckerath; and on the 18th may I again bid you farewell?

Yours, with hearty greetings,

JoHaNNEs.

February 13. Brahms arrived to-day at half past twelve. He stayed to dinner, and related some interesting things. We 
heard this remark by the Duke of Meiningen to Muhlfeld: "When you want leave of absence and Brahms is in question you can always leave Meiningen, without asking me." This afternoon the clarinet quintet was to have been rehearsed at our house, for performance at Mannheim, not at Frankfort, the interpreters being the Heermann Quartet and Muhlfeld. At half past four the guests were all assembled: the Landgravine Anna von Hessen, Baroness Rothschild, and many others. But the Landgrave had not arrived, neither had Herr Mublfeld. The latter was expected at the Hotel Continental, but on telephoning found he had not arrived in Frankfort. Instead of the quintet, the $\mathbf{G}$ minor piano quartet of Brahms was performed, with Brahms himself at the piano. After that Schumann's F major trio was played. Grandmother was at the piano, with Herr Heermann and Hugo Becker at the desks. The trio was selected at the particular wish of Brabms, who desired to hear it again. Unfortunately it could not be played to the end, for grandmother felt rather indisposed, and so the finale was omitted. At the trio Brahms sat apart from the performers and the listeners at the table in the dining room, from whence he heard it. Before it was finished Stockhausen came in and was cordially greeted by Brahms. The latter inquired regarding the condition of little Julie Stockhausen, who is very ill, and has been in bed for three weeks. Stockhausen was very much depressed. He had but recently lost his elder daughter, and is moreover suffering from a serious weakness of the eyes which threatens total blindness. Johannes Hegar and Johannes Stockhausen, youngest son of the singer, are god-sons of Brahms.

In the evening $I$ attended the concert at the Opera House. The first number on the programme was the $F$ major symphony by Brahms. It being the anniversary of Richard Wagner's death, Conductor Rottenberg wanted to give only Wagner, with one Beethoven number; but when he heard that Brahms was coming to Frankfort, he changed his plans. Brahms appeared after the symphony. Sitting quite alone in a first-tier box he heard Carl Halir perform the Beethoven violin concerto. Later on the "Faust" overture and that to the "Meistersinger" were performed. Before the concert was over Brahms entered the manager's box, where he stayed to the end.

February 14. This morning at ten the quintet was rehearsed at Professor Hugo Heermann's,' Muhlfeld having arrived the night before. Grandmother took me along and we read the score. . . Brahms left with the others an hour later for Mannheim. At dinner grandmother expressed herself most enthusias- 
tically over the composition. Discussing different passages of the profound and grand work she frequently exclaimed: "If Papa (Schumann) could have lived to enjoy thatl . He would have been delighted beyond words." But she did not approve of Brahms's taking the piano part at the public performance of the clarinet sonatas to-morrow evening. She thought that he should have engaged a Frankfort pianist, for his by no means technically perfect playing only lessened the effect produced by his compositions. He had been told this by others, but he could not be induced to abide by their advice.

February 15. Brahms returned at midday from Mannheim with the Heermann Quartet. He came directly from the station to the "Saalbau" in order to rehearse his G minor piano quartet. He took dinner with us, in the course of which he related the following episode: During the rehearsal Conductor Kogel came and begged him to attend the Sunday night popular concert. The D major symphony and the "Academic Festival" overture would be performed, and Kogel hoped that he (Brahms) would not object if he took certain liberties with the symphony. "No, go right on," answered Brahms; "the police will not punish you." (Brahms was highly amused while saying this.) Kogel remained for some minutes during the rehearsal, at the conclusion of which Brahms exclaimed: "Well, gentlemen, I am entirely satisfied; or" - in a much louder tone - "does Herr Kogel know of any liberties that we might introduce?" Kogel had left, but everyone in the hall heard Brahms. . . Grandmother thought that the affair would soon be in all the newspapers and, after Brahms had left, was rather put out and regretted that Brahms was sometimes rash in saying things which he afterwards was sorry to have said. He of all men should be careful by reason of his too impulsive temperament.

In the evening, chamber music in the smaller hall. The Stimmung was most elevated, since Brahms desired personally to introduce his clarinet sonatas to Frankfort. The programme comprised: Sonata in $\mathrm{F}$ minor, for clarinet and piano; Piano quartet in G minor, Op. 25; Sonata in Eb major, for clarinet and piano; all by Brahms. The players were Brahms, Muhlfeld, Heermann, Bassermann, Welker, Hugo Becker.

Brahms entered in evening dress, which emphasized his corpulence. On the other hand, from afar his head and beard made a wonderful impression. I cannot remember ever having seen anything more impressive. A mighty wave of cheering greeted him. I was glad of the applause, for it was spontaneous. . . 
The Frankforters know who is in their midst. ' It was a glorious evening. Brahms looked aristocratic in his evening dress, but evidently he doesn't like to wear it; he perspired profusely and his face was very red. To-night he appeared rather out of sorts and did not seem to be interested in the applause at all. After each movement he rose reluctantly and, apparently angry, pointed a finger at Heermann. At the close there seemed no end to the applause, after Brahms and his associates had left the platform. They sat together in the artists' room, none willing to come out. The applause lasted for three minutes, ceased, and then began again. Brahms does not appear-the platform remains empty. At last the door opens and Hugo Becker flies out as if shot out of a blow-pipe; behind him Brahms, fiery red in the face and furious. Abruptly bowing they retire. The public is amused-8ome people laugh. Afterwards I ascertained that Brahms had requested Heermann, as concert-master, to come out with him, which he refused to do. (Of course.) This greatly enraged Brahms, who finally persuaded Hugo Becker to come to the platform. Brahms is still highly incensed. He will never again play with Heermann. He is not, he says, an actor, and will never look at Heermann again. . .

February 17. At ten o'clock Brahms took me with him to the rehearsal for to-night's Sunday concert. As we entered the hall the first movement of the symphony had already been performed. Kogel came down from the stage, and greeted Brahms, who took a seat and listened. He had something to say after each movement. The third movement was taken much too fastthe inherited sin of all conductors, especially in this movement. After the symphony Brahms, accompanied by Kogel, ascended the platform, the orchestra greeting him with a fanfarel $\mathrm{He}$ bowed and delivered a few remarks in which he highly complimented Kogel. I distinctly heard him say: "The orchestra should congratulate itself upon its very capable conductor."

Afterwards be conducted the "Academic Festival" overture. I shall never forget his conducting-the concise, calm gestures, the serious expression of the face, the amiable directions to the different instrumental groups.

Muhlfeld performed Weber's $\mathbf{E}$ major concerto for clarinet, the strings played Handel's Concerto grasso No. 10, arranged by Kogel, and then Brahms, Muhlfeld and I walked through the town out to my Uncle Sommerhoff's farm. The menu included Brahms's favorite dish: sauerkraut. But the costly, old Rhine wine which my uncle served to Brahms he drank mixed with 
waterl On the way Brahms spoke to me about serving in the army. "It is much better," said he, "to serve when young than to become an old recruit." Muhlfeld agreed. The Master expressed repeatedly his deep regret that he had not served in the army. . .

February 19. Brahms returned from Rlidesheim at noon. He presented grandmother the menu designed at Rudesheim. It represented a lion comfortably reclining upon a pedestal, the front legs crossed: the head was that of Brahms. It was cleverly symbolized, vis.: Brahms, the powerful man resting after his great work, and enjoying his fame. At night company again. Grandmother desired to give Brahms as much entertainment as possible, and besides did not want him to be alone on this, his last night at Frankfort. To-morrow he leaves. Brahms shared Urspruch's opinion about conservatories in which practically only piano-playing was taught. Real musicians such institutions could not develop. . .

February 21. While Brahms was yesterday listening to a pupil play Schumann's "Bird as Prophet" he remarked that it was one of Rubinstein's greatest pieces. No living pianist can be compared with him. The good players of the present day have no touch. Of Berlioz's overture, "Romeo and Juliet," he remarked that it was very tedious and contained only two fine passages. It is to be given at to-night's "Museum" concert.

Septomber 8 (Interlaken). As in former years, grandmother is spending the entire summer here. She gets very angry whenever she reads or hears some one say that as a creative artist Rubinstein is the equal of Brahms. "Brahms is without a rival and stands alone among the living." That's her opinion.

Professor Stockhausen came to-day to say good-bye. He returns to Frankfort. Wagner was constantly discussed. Grandmother and Stockhausen are of the opinion that Wagner will one day totally disappear. His music, they argue, is too unhealthy; the coloring is good, but the drawing bad. However, they grant that he a genius. Levi ${ }^{1}$ was not a fanatical Wagnerite, like Mottl and Richard Strauss, for there still dwelt something of the classical school in him. The estrangement between Brahms and Levi is alluded to. Formerly Levi was one of his warmest admirers. But when Wagner's fame began to rise, and while Brahms was visiting Levi in Munich, Levi one day spoke of Gluck and

2 Hermann Levi, the great Munich director and firt conductor of "Parsifal." Lev's claselcism is thown in his admirable editions of Mozart's operas, which aro used in the Munich productions to this very dey.-Tr. 
Wagner in the same sentence. "These names are not to be mentioned in the same breath," Brahms angrily remarked, and left the room. The next day he departed from Munich. Since then Levi became a bitter opponent of Brahms and expressed himself with incredible harshness about his music.

October 3 . Since the end of last month we are again in Frankfort. To-day, on my twentieth birthday, Brahms arrived here at five o'clock. At tea I saw him. After congratulating me he spoke of the musical festival at Meiningen. It was very fine. He praised the Meiningen opera singer, Ludwig Wullner, who interpreted his songs better than anyone else.

In the evening, Brahms and Stockhausen at supper. We were joined by Professor Kufferath, ${ }^{1}$ of Brussels, and Mr. and Mrs. Edward Speyer, of London. After supper Frau Speyer (nbe Kufferath) rendered some songs by Brahms, among others "In stiller Nacht," from the folk-song collection. The Master accompanied.

October 4. Brahms left for Vienna this afternoon. He therefore came this time only to see grandmother. Mr. and Mrs. Speyer and I were at the station. The Master stepped into a first-class compartment, closed the door and, looking out of the window, indulged in all sorts of pranks. . . In the morning I had gone to Schepeler in the Rossmarket to procure some tobacco for him. He had written the kind he wanted on this slip of paper which I still possess: "Cigarette tobacco Caporal, blue paper, (50 pfg.), small size, 5 packages." At home I handed it to him. He placed it in his satchel. When grandmother asked him what he intended to do with so much tobacco, he exclajmed, laughing: "Smuggle it through, Clara!"

October 5. To-day I took to Dr. Ludwig Rottenberg a manuscript of Brahms at his request. It was the song, "Uber die Haide hallet mein Schritt," (poem by Storm), with this inscription by Brahms: "To Ludwig Rottenberg, wishing him a joyous pilgrimage, Johannes Brahms."

Rottenberg had recently become engaged.

Yesterday Brahms said to grandmother that he no longer composed for the public, but only for himself. One composes only until one's fiftieth year. Then the creative power begins to diminish. Even though he had composed the clarinet quartet at fifty-five, one must always bear in mind that fact.

2 The eminent Belginn murical critic-Tr. 